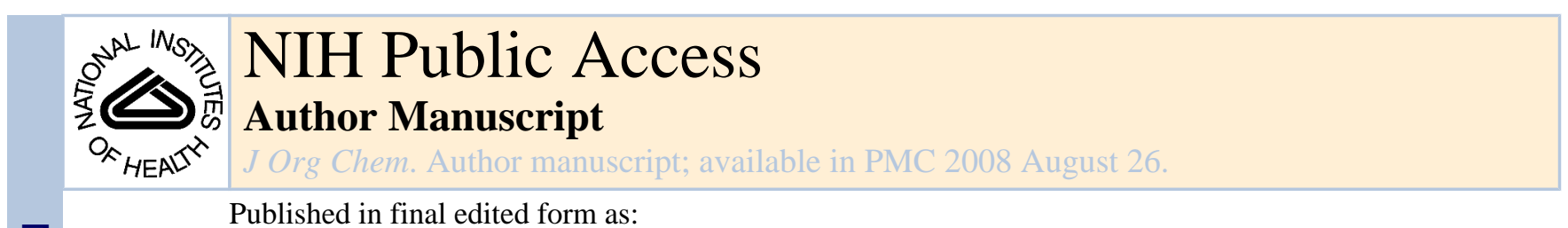

Published in final edited form as:

J Org Chem. 2007 July 20; 72(15): 5839-5842. doi:10.1021/jo0707885.

\title{
Rational Routes to Formyl-Substituted Chlorins
}

\author{
Chinnasamy Muthiah, Jayeeta Bhaumik, and Jonathan S. Lindsey* \\ Department of Chemistry, North Carolina State University, Raleigh, North Carolina 27695-8204
}

\begin{abstract}

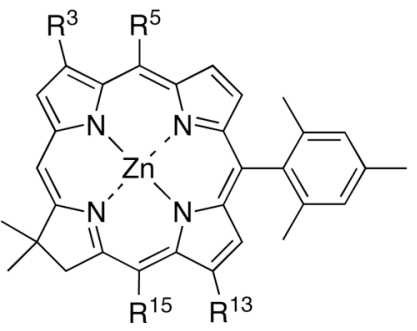

synthetic chlorins

$\mathrm{R}=\mathrm{H}, p$-tolyl ( $\mathrm{R}^{5}$ only) or $\mathrm{CHO}$

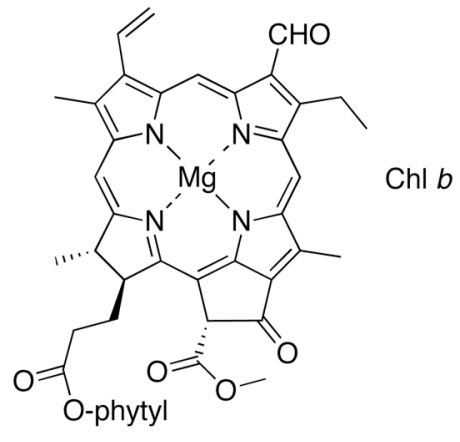

Two distinct approaches have been developed for the synthesis of chlorins bearing formyl groups: (1) reaction of an acetal-substituted 1-acyldipyrromethane with 2,3,5,6-tetrahydro-1,3,3trimethyldipyrrin to give upon hydrolysis a 5-formylchlorin; (2) Pd-mediated coupling of a bromochlorin with a one-carbon synthon (hydroxymethyl tributyltin or CO) to give a 13-, 15-, or 3,13 -formylchlorin. The zinc chlorins exhibit long-wavelength peak absorption maxima ranging from 626 to $667 \mathrm{~nm}$, indicating the wavelength tunability afforded by formyl substitution.
\end{abstract}

Formyl-substituted porphyrins have proved valuable for fundamental spectroscopic studies and as versatile synthetic intermediates. ${ }^{1}$ Formyl-substituted chlorins have provoked interest owing to the distinct spectra provided by chlorophyll $b$, which contains a formyl group at the 7-position, versus chlorophyll $a$, which contains a 7-methyl group. The formyl group also provides a valuable site for synthetic elaboration of chlorins, ${ }^{2-5}$ although the synthesis of formylchlorins has presented a number of challenges.

One popular synthetic approach has been to use chlorophyll $b$ directly in derivatization processes, including formation of the imine, ${ }^{6}$ olefin, ${ }^{7}$ or the meso-carbon of an attached porphyrin. ${ }^{2} \mathrm{~A}$ second approach has been to formylate an intact chlorin. This approach is largely restricted to simple substituted chlorins (e.g., $\beta$-octaethylchlorin 8,9 or meso-

tetraarylchlorins ${ }^{10}$ ) so as to avoid formation of regioisomers, although one notable exception is the regioselective 20 -formylation of selected naturally occurring chlorins. ${ }^{8,11} \mathrm{~A}$ third approach entails the modification of naturally occurring chlorins such as chlorophyll $a$. Examples include (i) oxidation of a 3 -vinyl group to give a 3 -formyl species, ${ }^{12}$ (ii) oxidation of an 8-vinyl group to give an 8-formyl species, ${ }^{13}$ (iii) rupture of the isocyclic ring followed by functional group transformations to give the 13 -formylchlorin ${ }^{12,14}$ or 15 -formylchlorin, 15 and (iv) derivatization of alkyl groups at the 8- or 12-positions. 5,16 The ability to place formyl groups at designated sites in chlorins would benefit from more versatile methods of 
synthesis, particularly methods that do not rely on naturally occurring chlorins as starting materials.

We recently prepared a family of chlorins bearing auxochromes at the 3-and 13-positions. 17,18 The chlorins were prepared by de novo synthesis and contained a geminal dimethyl group in the reduced ring to ensure stability toward adventitious oxidation. The substituents were introduced at the 3,13-positions because the transition that gives rise to the long-wavelength $\left(\mathrm{Q}_{\mathrm{y}}\right)$ band is polarized along this axis. The auxochromes included phenyl, vinyl, TIPS-ethynyl, and acetyl, of which the acetyl group gave the most pronounced changes in the absorption spectra. The presence of a single acetyl group at the 13-position caused a $26 \mathrm{~nm}$ redshift, whereas 3,13-diacetyl substitution caused a $56 \mathrm{~nm}$ redshift. On the other hand, similar groups at the 15-position caused much smaller effects. ${ }^{19}$ Extension of this approach to synthetic chlorins bearing formyl groups at specific positions is of great interest because the formyl group is expected to be a more potent auxochrome than acetyl, ethynyl, or vinyl. Toward, this goal, we report herein two rational routes to chlorins that enable placement of formyl groups at designated sites, including the 5-, 13-, 15- and 3,13-positions.

\section{Synthesis of a 5-Formylchlorin from an Acetal-dipyrromethane}

The synthesis of a 5-formylchlorin was approached through use of a 1-acyldipyrromethane that contains a protected formyl group (1) ${ }^{20}$ Other acetal-chlorins have been prepared by reduction of the corresponding porphyrin ${ }^{21}$ or from the formylchlorin. ${ }^{22} 1$ -

Acyldipyrromethane 1 was treated with $\mathrm{NBS}^{23}$ at $-78^{\circ} \mathrm{C}$ for $1 \mathrm{~h}$ to afford the corresponding 1-bromo-9-acyldipyrromethane (2) in 79\% yield (Scheme 1). Reduction of 2 with $\mathrm{NaBH}_{4}$ afforded the 1-bromo-dipyrromethane-9-carbinol (Eastern half). The latter was immediately subjected to condensation ${ }^{23}$ with tetrahydrodipyrrin $3^{24}$ (Western half) in the presence of TFA to obtain the tetrahydrobilene- $a$ derivative, which upon oxidative cyclization gave the 5-acetalsubstituted zinc chlorin 4 in 16\% yield. The acetal group was hydrolyzed (and the zinc chlorin was demetalated) by treatment with TFA/ $\mathrm{H}_{2} \mathrm{O}$ in $\mathrm{CH}_{2} \mathrm{Cl}_{2}$, thereby affording the free base formylchlorin $\mathbf{F b C}-\mathbf{F}^{\mathbf{5}} \mathbf{P}^{\mathbf{1 0}}$ in $84 \%$ yield. Treatment of $\mathbf{F b C}-\mathbf{F}^{\mathbf{5}} \mathbf{P}^{\mathbf{1 0}}$ with $\mathrm{Zn}(\mathrm{OAc})_{2} \cdot 2 \mathrm{H}_{2} \mathrm{O}$ afforded the zinc chelate $\mathbf{Z n C}-\mathbf{F}^{\mathbf{5}} \mathbf{P}^{\mathbf{1 0}}$ in quantitative yield.

\section{Synthesis of Formylchlorins from Bromochlorins}

To more generally introduce formyl groups at various $\beta$-positions, we first investigated Stille coupling of a bromochlorin and hydroxymethyltributyltin 25,26 to give the corresponding hydroxymethylchlorin (Scheme 2). The zinc chelate of the 13-bromochlorin $\left(\mathbf{Z n C}-\mathbf{M}^{\mathbf{1 0}} \mathbf{B r}^{\mathbf{1 3}}\right.$ ) 17 gave limited conversion upon refluxing with THF. Demetalation of $\mathbf{Z n C}-\mathbf{M}^{\mathbf{1 0}} \mathbf{B r}^{\mathbf{1 3}}$ with TFA afforded the crude free base chlorin. Coupling of the latter and $\mathrm{Bu}_{3} \mathrm{SnCH}_{2} \mathrm{OH}$ in the presence of $\mathrm{Pd}\left(\mathrm{PPh}_{3}\right)_{4}$ in THF for $30 \mathrm{~h}$ gave the 13-hydroxymethylchlorin 5 in $51 \%$ yield. The oxidation of $\mathbf{5}$ with $\mathrm{MnO}_{2}$ in toluene at room temperature afforded the 13-formylchlorin $\mathbf{F b C}$ $\mathbf{M}^{\mathbf{1 0}} \mathbf{F}^{\mathbf{1 3}}$ in $91 \%$ yield. The free base formylchlorin $\mathbf{F b C}-\mathbf{T}^{\mathbf{5}} \mathbf{M}^{\mathbf{1 0}} \mathbf{F}^{\mathbf{1 3}}$ was obtained similarly (Scheme 2). A streamlined procedure including demetalation, Pd-coupling, and oxidation gave $\mathbf{F b C}-\mathbf{T}^{\mathbf{5}} \mathbf{M}^{\mathbf{1 0}} \mathbf{F}^{\mathbf{1 3}}$ in $47 \%$ yield starting from $\mathbf{Z n C}-\mathbf{T}^{\mathbf{5}} \mathbf{M}^{\mathbf{1 0}} \mathbf{B} \mathbf{r}^{\mathbf{1 3}}$.

We next investigated the more direct method of Pd-mediated reductive carbonylation. ${ }^{27,28} \mathrm{~A}$ short survey of conditions (solvent, palladium source, and amount of $\mathrm{HCO}_{2} \mathrm{Na}$ ) identified effective conditions. Thus, treatment of $\mathbf{Z n C}-\mathbf{M}^{\mathbf{1 0}} \mathbf{B r}^{\mathbf{1 3}}(10 \mathrm{mM})$ with sodium formate $(20 \mathrm{mM})$ in the presence of $\left(\mathrm{PPh}_{3}\right)_{2} \mathrm{PdCl}_{2}(20 \mathrm{~mol} \%)$ and $\mathrm{PPh}_{3}(20 \mathrm{~mol} \%)$ in DMF at $108{ }^{\circ} \mathrm{C}$ under an atmosphere of $\mathrm{CO}$ afforded the 13 -formylchlorin $\mathbf{Z n C}-\mathbf{M}^{\mathbf{1 0}} \mathbf{F}^{\mathbf{1 3}}$ in $68 \%$ yield. This Pd-mediated carbonylation method was successfully applied to introduce the formyl group into the chlorin macrocycle at the 13-, 3,13-, and 15-positions (Table 1). 


\section{Absorption Spectra of Formylchlorins}

The absorption spectra of the formylchlorins (in toluene at room temperature) are summarized in Table 2. Three classes are noted: zinc chlorins bearing a 10-mesityl group (ZnC-M $\mathbf{M}^{\mathbf{1 0}}$ series); zinc chlorins bearing a 5-p-tolyl group and a 10-mesityl group (ZnC-T ${ }^{\mathbf{5}} \mathbf{M}^{\mathbf{1 0}}$ series); and various free base chlorins (FbC series). Selected absorption spectra of the $\mathbf{Z n C}-\mathbf{M}^{\mathbf{1 0}}$ series are shown in Figure 1 (see Supporting Information for additional spectra).

The presence of a formyl group at the 3-, 5-, 13-, or 15-positions causes a redshift of the longwavelength absorption $\left(\mathrm{Q}_{\mathrm{y}}\right)$ band. However, the magnitude of the redshift, the sharpness of the $\mathrm{Q}_{\mathrm{y}}$ band, and the intensity of the $\mathrm{Q}_{\mathrm{y}}$ band relative to the band in the blue region ( $\mathrm{B}$ band) depend on the position of substitution. The major observations are as follows:

1. A 13-formyl group causes a redshift of $730 \mathrm{~cm}^{-1}\left(28 \mathrm{~nm} ; \mathbf{Z n C}-\mathbf{M}^{\mathbf{1 0}} \mathbf{F}^{\mathbf{1 3}}\right.$ versus $\mathbf{Z n C}$ $\left.\mathbf{M}^{10}\right)$, to be compared with only $680 \mathrm{~cm}^{-1}(26 \mathrm{~nm})$ for the corresponding 13acetylchlorin ${ }^{17}\left(\mathbf{Z n C}-\mathbf{M}^{\mathbf{1 0}} \mathbf{A}^{\mathbf{1 3}}\right)$. The relative intensity of the $\mathrm{Q}_{\mathrm{y}}$ band increases by approximately two-fold for $\mathbf{Z n C}-\mathbf{M}^{\mathbf{1 0}} \mathbf{F}^{\mathbf{1 3}}$ versus $\mathbf{Z n C}-\mathbf{M}^{\mathbf{1 0}}$ while the sharpness (fwhm) remains relatively constant $(12 \mathrm{~nm})$. Note that the 10-mesityl and 10-phenyl groups give essentially identical spectra. ${ }^{19}$

2. 3,13-Diformyl groups cause a redshift of $1500 \mathrm{~cm}^{-1}\left(61 \mathrm{~nm} ; \mathbf{Z n C}-\mathbf{F}^{\mathbf{3}} \mathbf{M}^{\mathbf{1 0}} \mathbf{F}^{\mathbf{1 3}}\right.$ versus ZnC-M ${ }^{10}$ ), to be compared with $1400 \mathrm{~cm}^{-1}(56 \mathrm{~nm})$ for the corresponding 3,13diacetylchlorin ${ }^{17}\left(\mathbf{Z n C}-\mathbf{A}^{\mathbf{3}} \mathbf{M}^{\mathbf{1 0}} \mathbf{A}^{\mathbf{1 3}}\right)$. A further increase in relative intensity of the $\mathrm{Q}_{\mathrm{y}}$ band occurs $\left(\mathrm{I}_{\mathrm{B}} / \mathrm{I}_{\mathrm{Q}}=1.4\right.$ for $\mathbf{Z n C}-\mathbf{F}^{\mathbf{3}} \mathbf{M}^{\mathbf{1 0}} \mathbf{F}^{\mathbf{1 3}}$ versus 4.3 for $\left.\mathbf{Z n C}-\mathbf{M}^{\mathbf{1 0}}\right)$ while the sharpness (fwhm) decreases only modestly $(17 \mathrm{~nm})$.

3. A 5-formyl group causes a strong redshift of $1100 \mathrm{~cm}^{-1}$ (44 nm; $\mathbf{Z n C}-\mathbf{F}^{\mathbf{5}} \mathbf{P}^{\mathbf{1 0}}$ versus ZnC-P10), which is more pronounced than at any other single site examined herein. However, the $\mathrm{Q}_{\mathrm{y}}$ band is relatively broad ( $\mathrm{fwhm}=36 \mathrm{~nm}$ ).

4. A 15-formyl group causes a modest redshift of $470 \mathrm{~cm}^{-1}\left(18 \mathrm{~nm} ; \mathbf{Z n C}-\mathbf{T}^{\mathbf{5}} \mathbf{M}^{\mathbf{1 0}} \mathbf{F}^{\mathbf{1 5}}\right.$ versus $\mathbf{Z n C}-\mathbf{T}^{\mathbf{5}} \mathbf{M}^{\mathbf{1 0}}$ ), band broadening ( $\mathrm{fwhm}=20 \mathrm{~nm}$ ), and no increase in the relative intensity of the $\mathrm{Q}_{\mathrm{y}}$ band $\left(\mathrm{I}_{\mathrm{B}} / \mathrm{I}_{\mathrm{Q}}=5.6\right.$ for $\mathbf{Z n C}-\mathbf{T}^{\mathbf{5}} \mathbf{M}^{\mathbf{1 0}} \mathbf{F}^{\mathbf{1 5}}$ versus 5.0 for $\mathbf{Z n C}$ $\left.\mathbf{T}^{5} \mathbf{M}^{10}\right)$.

Thus, the formyl group is a slightly more potent auxochrome than the acetyl group at those positions where comparisons can be made (13- or 3,13-positions), causing bathochromic and hyperchromic effects without substantial band broadening. The bathochromic shift increases in order of positions $5<13<15$, whereas the band-broadening effect increases in order of positions $13<15<5$. Similar trends were noted in the free base chlorins where comparisons can be made.

In summary, we have developed rational approaches for the synthesis of formylchlorins. Pdmediated formylation is attractive where suitable bromochlorins are available (positions 3, 13, 15 , etc.), otherwise a complementary route entails construction of a chlorin with use of an acetal-substituted precursor (e,g., 5-position). Both approaches were successfully implemented to give milligram quantities of formylchlorins. The absorption spectra of zinc chelates of 5-, 13-, 3,13- and 15-formylchlorins revealed a significant effect of the formyl group depending on the position of substitution. The long-wavelength absorption band can now be tuned over the range of $606-667 \mathrm{~nm}$. For applications in flow cytometry, the chlorins with distinct and sharp bands could provide a panel of fluorophores. For applications in solar energy conversion, the collection of wavelength-tunable chlorins, including the chlorins with broad bands, could provide enhanced solar coverage. Taken together, the routes described herein afford versatile access to formylchlorins for use in fundamental spectroscopic studies and further synthetic elaboration. 


\section{Experimental Section}

\section{Carbonylation Procedure: Zn(II)-3,13-Diformyl-17,18-dihydro-18,18-dimethyl-10- mesitylporphyrin $\left(\mathrm{ZnC}-\mathrm{F}^{3} \mathrm{M}^{10} \mathrm{~F}^{13}\right)$}

Following a procedure for CO-mediated formylation, ${ }^{28}$ a mixture of $\mathbf{Z n C}-\mathbf{B r}^{\mathbf{3}} \mathbf{M}^{\mathbf{1 0}} \mathbf{B r}^{\mathbf{1 3}}(13.8$ $\mathrm{mg}, 0.0203 \mathrm{mmol}),\left(\mathrm{PPh}_{3}\right)_{2} \mathrm{PdCl}_{2},(2.85 \mathrm{mg}, 0.00406 \mathrm{mmol}, 20 \mathrm{~mol} \%), \mathrm{PPh}_{3}(1.06 \mathrm{mg}, 0.00406$ $\mathrm{mmol}, 20 \mathrm{~mol} \%)$ and sodium formate $(3.50 \mathrm{mg}, 0.0507 \mathrm{mmol})$ was dried in a Schlenk flask for $1 \mathrm{~h}$. DMF $(1.2 \mathrm{~mL})$ was added, and $\mathrm{CO}$ gas was bubbled through the reaction mixture for $2 \mathrm{~h}$ at $108^{\circ} \mathrm{C}$. Then, the reaction mixture was heated at $108^{\circ} \mathrm{C}$ under a balloon containing $\mathrm{CO}$ for $24 \mathrm{~h}$. After cooling to room temperature, the reaction mixture was treated with $\mathrm{CH}_{2} \mathrm{Cl}_{2}$ and water. The organic layer was separated, washed (water, brine), dried $\left(\mathrm{Na}_{2} \mathrm{SO}_{4}\right)$ and concentrated. The resulting residue was chromatographed [silica, hexanes $/ \mathrm{CH}_{2} \mathrm{Cl}_{2}(1: 2) \rightarrow$ $\mathrm{CH}_{2} \mathrm{Cl}_{2} \rightarrow \mathrm{CH}_{2} \mathrm{Cl}_{2}$ /ethyl acetate (7:1)] to afford a trace amount ( $\sim 5 \%$ of the total) of a monoformylated chlorin followed by the title compound as a green solid $(6.1 \mathrm{mg}, 52 \%):{ }^{1} \mathrm{H}$ NMR $(300 \mathrm{MHz}) \delta 1.82(\mathrm{~s}, 6 \mathrm{H}), 2.03(\mathrm{~s}, 6 \mathrm{H}), 2.60(\mathrm{~s}, 3 \mathrm{H}) 4.53(\mathrm{~s}, 2 \mathrm{H}), 7.23(\mathrm{~s}, 2 \mathrm{H}), 8.38(\mathrm{~d}, J=4.5$ $\mathrm{Hz}, 1 \mathrm{H}), 8.62(\mathrm{~s}, 1 \mathrm{H}), 8.87(\mathrm{~d}, J=4.5 \mathrm{~Hz}, 1 \mathrm{H}), 9.00(\mathrm{~s}, 1 \mathrm{H}), 9.26(\mathrm{~s}, 1 \mathrm{H}), 9.61(\mathrm{~s}, 1 \mathrm{H}), 10.3$ $(\mathrm{s}, 1 \mathrm{H}), 10.88(\mathrm{~s}, 1 \mathrm{H}), 11.15(\mathrm{~s}, 1 \mathrm{H}) ;{ }^{13} \mathrm{C}$ NMR $\delta 188.8,188.7,172.8,167.4,162.1,161.5$, $160.8,144.0,141.9,140.2,138.9,137.9,137.5,135.8,135.7,131.9,130.6,128.2,128.1,110.3$, 107.7, 98.3, 96.6, 94.5, 50.5, 44.3, 31.0, 21.4, 21.2; LDMS obsd 576.8; FAB-MS obsd 576.1499, calcd 576.1504 $\left(\mathrm{C}_{33} \mathrm{H}_{28} \mathrm{~N}_{4} \mathrm{O}_{2} \mathrm{Zn}\right) ; \lambda_{\text {abs }}$ (toluene) $439,667 \mathrm{~nm}$.

\section{Streamlined Procedure via Hydroxymethylation: 13-Formyl-17,18-dihydro-18,18- dimethyl-10-mesityl-5-p-tolylporphyrin ( $\mathrm{FbC}-\mathrm{T}^{5} \mathrm{M}^{10} \mathrm{~F}^{13}$ )}

A sample of chlorin $\mathbf{Z n C}-\mathbf{T}^{\mathbf{5}} \mathbf{M}^{\mathbf{1 0}} \mathbf{B r}^{\mathbf{1 3}}$ (7.50 $\mathrm{mg}, 0.0108 \mathrm{mmol}$ ) was treated with TFA (25.0 $\mu \mathrm{l}, 0.324 \mathrm{mmol})$ in $\mathrm{CH}_{2} \mathrm{Cl}_{2}(1.0 \mathrm{~mL})$. The reaction mixture was stirred at room temperature for $3 \mathrm{~h}$. The reaction mixture was quenched by the addition of a mixture of saturated aqueous $\mathrm{NaHCO}_{3}$ and $\mathrm{CH}_{2} \mathrm{Cl}_{2}$. The organic layer was separated, washed (water, brine), dried $\left(\mathrm{Na}_{2} \mathrm{SO}_{4}\right)$ and concentrated to afford the free base chlorin. Following a procedure for Stille coupling with chlorins, ${ }^{17}$ a mixture of free base chlorin $(\sim 0.0108 \mathrm{mmol})$ and $\mathrm{Pd}\left(\mathrm{PPh}_{3}\right)_{4}(2.50$ $\mathrm{mg}, 0.00216 \mathrm{mmol}$ ) was dried in a Schlenk flask for $30 \mathrm{~min}$. Hydroxymethyltributyltin (13.8 $\mathrm{mg}, 0.0432 \mathrm{mmol})$ in THF $(1.0 \mathrm{~mL})$ was added, and the reaction mixture was refluxed for 30 $\mathrm{h}$. The reaction mixture was concentrated. The resulting residue was dissolved in toluene $(0.20$ $\mathrm{mL})$, and $\mathrm{MnO}_{2}(47.0 \mathrm{mg}, 0.540 \mathrm{mmol})$ was added. The reaction mixture was stirred at room temperature for $1 \mathrm{~h}$. The reaction mixture was concentrated and chromatographed [silica, hexanes $\rightarrow$ hexanes $\left./ \mathrm{CH}_{2} \mathrm{Cl}_{2}(1: 1) \rightarrow(2: 8)\right]$ to afford a purple solid (3.0 $\left.\mathrm{mg}, 47 \%\right)$ with characterization data $\left({ }^{1} \mathrm{H}\right.$ NMR, ${ }^{13} \mathrm{C}$ NMR, LD-MS, FAB-MS, UV-Vis) consistent with those for the product obtained via individual stepwise procedures (see Supporting Information).

\section{Supplementary Material}

Refer to Web version on PubMed Central for supplementary material.

\section{Acknowledgements}

This work was supported by the NIH (GM36238).

\section{References}

1. Ponomarev GV. Chem Heterocyclic Compounds 1994;30:1444-1465.

2. Wasielewski MR. Chem Rev 1992;92:435-461.

3. Jaquinod L, Nurco DJ, Medforth CJ, Pandey RK, Forsyth TP, Olmstead MM, Smith KM. Angew Chem Int Ed Engl 1996;35:1013-1016. 
4. Wang JJ, Shim YK, Jiang GJ, Imafuku K. J Heterocyclic Chem 2003;40:1075-1079.

5. Li G, Dobhal MP, Shibata M, Pandey RK. Org Lett 2004;6:2393-2396. [PubMed: 15228287]

6. Losev A, Mauzerall D. Photochem Photobiol 1983;38:355-361.

7. Tamiaki H, Kouraba M. Tetrahedron 1997;53:10677-10688.

8. Smith KM, Bisset GMF, Bushell MJ. Bioorg Chem 1980;9:1-26.

9. Kalisch WW, Senge MO, Ruhlandt-Senge K. Photochem Photobiol 1998;67:312-323.

10. Mironov AF, Moskalchuk TV, Shashkov AS. Russ J Bioorg Chem 2004;30:261-267.

11. Ando T, Irie K, Koshimizu K, Takemura T, Nishino H, Iwashima A, Nakajima S, Sakata I. Tetrahedron 1990;46:5921-5930.

12. Kunieda M, Tamiaki H. J Org Chem 2007;72:2443-2451. [PubMed: 17338568]

13. Sasaki SI, Tamiaki H. Bull Chem Soc Jpn 2004;77:797-800.

14. Ma L, Dolphin D. Tetrahedron Lett 1995;36:7791-7794.

15. Wray V, Jürgens U, Brockmann H Jr. Tetrahedron 1979;35:2275-2283.

16. Zheng G, Potter WR, Camacho SH, Missert JR, Wang G, Bellnier DA, Henderson BW, Rodgers MAJ, Dougherty TJ, Pandey RK. J Med Chem 2001;44:1540-1559. [PubMed: 11334564]

17. Laha JK, Muthiah C, Taniguchi M, McDowell BE, Ptaszek M, Lindsey JS. J Org Chem 2006;71:40924102. [PubMed: 16709048]

18. Kee HL, Kirmaier C, Tang Q, Diers JR, Muthiah C, Taniguchi M, Laha JK, Ptaszek M, Lindsey JS, Bocian DF, Holten D. Photochem Photobiol 2007;83in press

19. Kee HL, Kirmaier C, Tang Q, Diers JR, Muthiah C, Taniguchi M, Laha JK, Ptaszek M, Lindsey JS, Bocian DF, Holten D. Photochem Photobiol 2007;83in press

20. Balakumar A, Muthukumaran K, Lindsey JS. J Org Chem 2004;69:5112-5115. [PubMed: 15255746]

21. Balaban TS, Linke-Schaetzel M, Bhise AD, Vanthuyne N, Roussel C. Eur J Org Chem 2004:3919_ 3930.

22. Tamiaki H, Kubo M, Oba T. Tetrahedron 2000;56:6245-6257.

23. Taniguchi M, Ra D, Mo G, Balasubramanian T, Lindsey JS. J Org Chem 2001;66:7342-7354. [PubMed: 11681947]

24. Ptaszek M, Bhaumik J, Kim HJ, Taniguchi M, Lindsey JS. Org Process Res Dev 2005;9:651-659.

25. a Kosugi M, Sumiya T, Ogata T, Sano H, Migita T. Chem Lett 1984:1225-1226. b Kosugi M, Sumiya T, Ohhashi K, Sano H, Migita T. Chem Lett 1985:997-998.

26. a Åhman J, Somfai P. Synth Commun 1994;24:1117-1120. b Danheiser RL, Romines KR, Koyama H, Gee SK, Johnson CR, Medich JR. Org Synth 1993;71:133-139.

27. Pri-Bar I, Buchman O. J Org Chem 1984;49:4009-4011.

28. Okano T, Harada N, Kiji J. Bull Chem Soc Jpn 1994;67:2329-2332.

29. Laha JK, Muthiah C, Taniguchi M, Lindsey JS. J Org Chem 2006;71:7049-7052. [PubMed: 16930061]

30. Taniguchi M, Kim MN, Ra D, Lindsey JS. J Org Chem 2005;70:275-285. [PubMed: 15624933] 


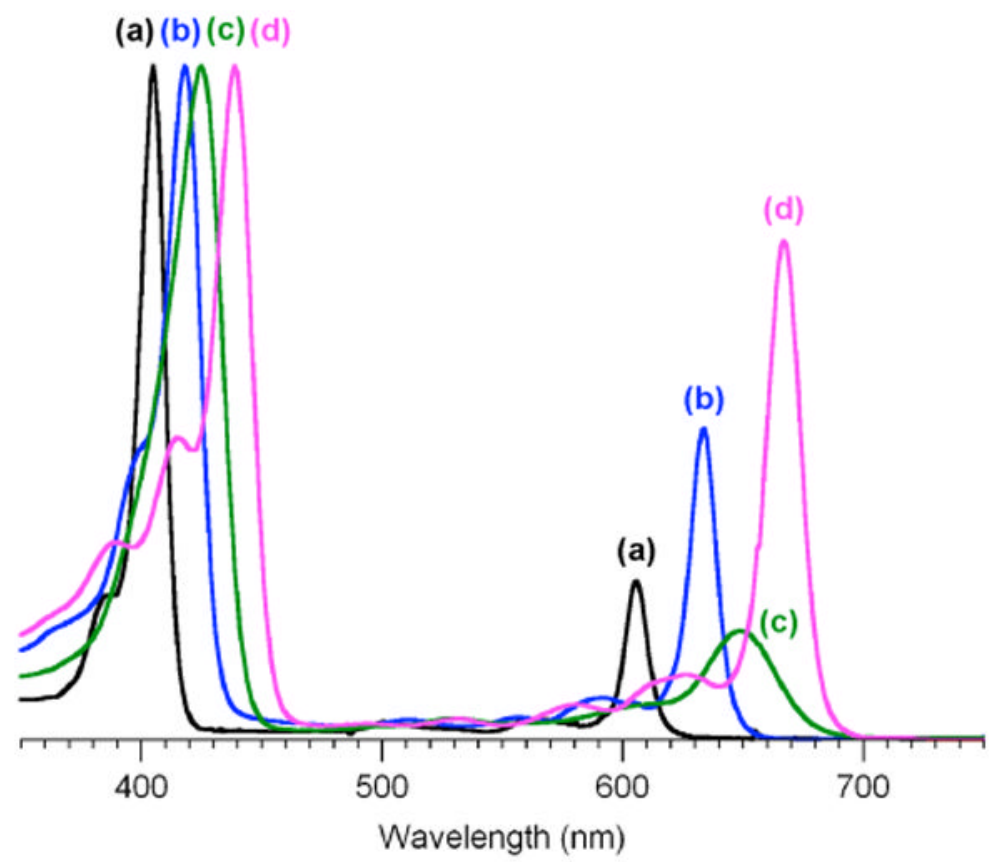

Figure 1.

Absorption spectra (normalized) in toluene at room temperature of $\mathbf{Z n C}-\mathbf{M}^{\mathbf{1 0}}$ (trace a, $\lambda_{\mathrm{Qy}} 606$ $\mathrm{nm}){ }^{17} \mathbf{Z n C}-\mathbf{M}^{\mathbf{1 0}} \mathbf{F}^{\mathbf{1 3}}$ (trace b, $\lambda_{\text {Qy }} 634 \mathrm{~nm}$ ), ZnC-F $\mathbf{F}^{\mathbf{5} \mathbf{P}^{\mathbf{0}}}$ (trace c, $\lambda_{\mathrm{Qy}} 650 \mathrm{~nm}$ ), and $\mathbf{Z n C}$ $\mathbf{F}^{\mathbf{3}} \mathbf{M}^{\mathbf{1 0}} \mathbf{F}^{\mathbf{1 3}}$ (trace d, $\lambda_{\mathrm{Qy}} 667 \mathrm{~nm}$ ). 

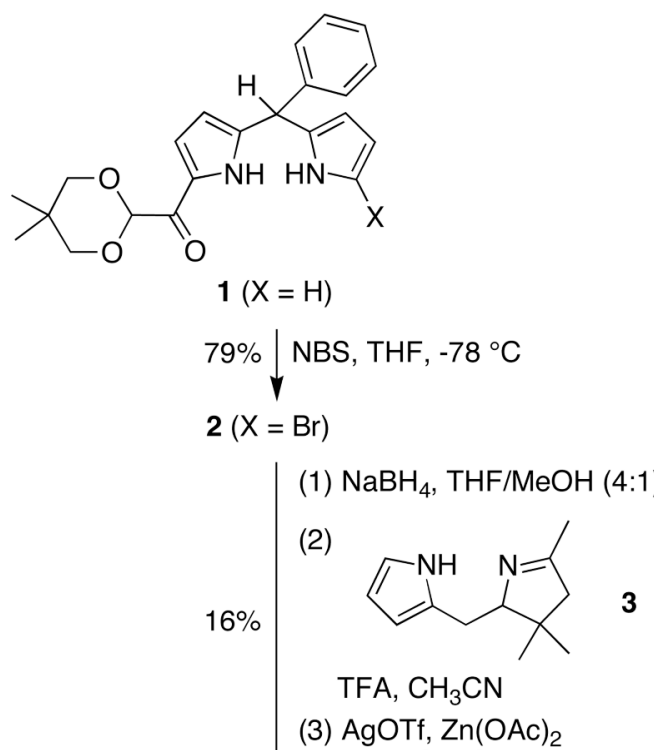

(3) $\mathrm{AgOTf}, \mathrm{Zn}(\mathrm{OAc})_{2}$

$\checkmark$

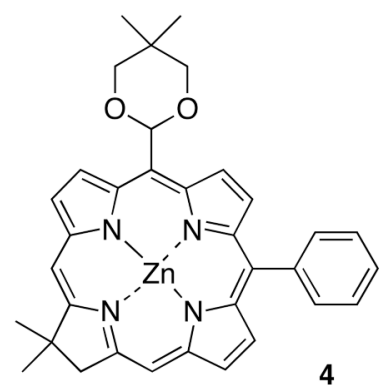

4

$84 \% \downarrow \mathrm{TFA} / \mathrm{H}_{2} \mathrm{O}, \mathrm{CH}_{2} \mathrm{Cl}_{2}$

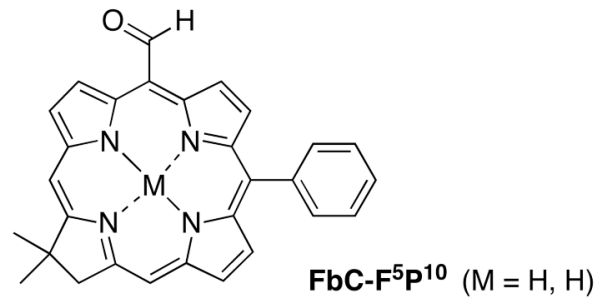

quant. $\mid \mathrm{Zn}(\mathrm{OAc})_{2} \cdot 2 \mathrm{H}_{2} \mathrm{O}$

ZnC-F ${ }^{5} \mathbf{P}^{10}(\mathrm{M}=\mathrm{Zn})$

Scheme 1. 


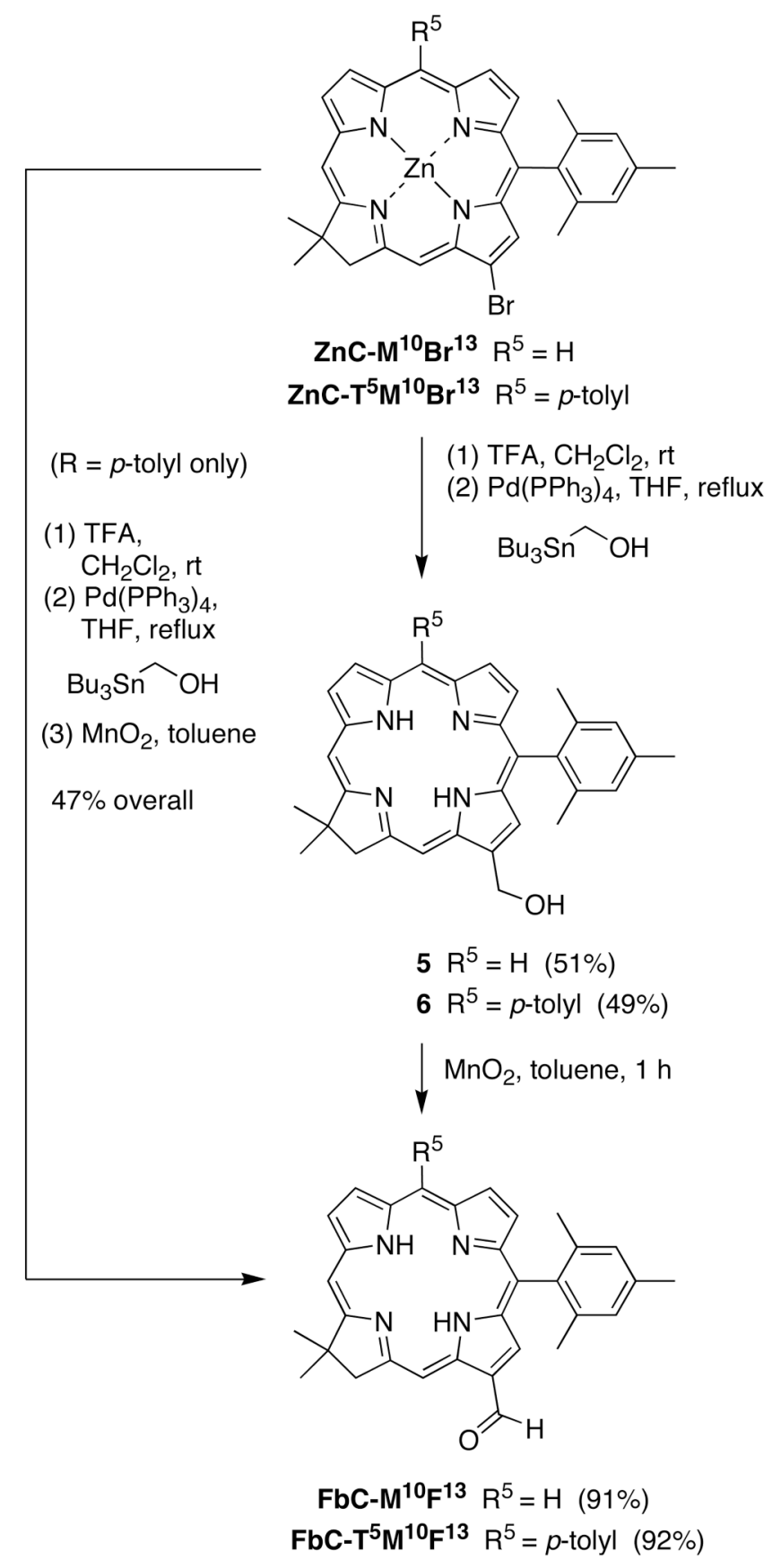

Scheme 2. 

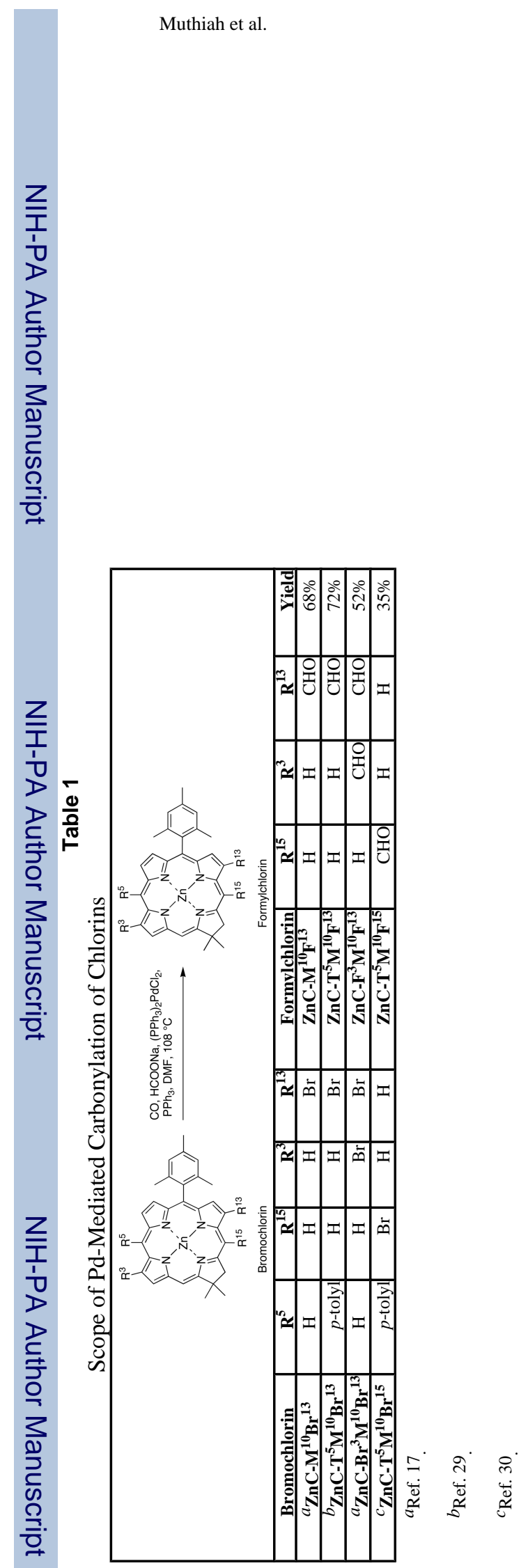


\section{Table 2}

Spectral Properties of Chlorins. ${ }^{a}$

\begin{tabular}{|c|c|c|c|c|}
\hline Compound $^{b}$ & $\lambda_{\mathrm{B}}(\mathrm{fwhm})$ in $\mathrm{nm}$ & $\lambda_{\mathrm{Qy}}(\mathrm{fwhm})$ in $\mathrm{nm}$ & $\mathbf{I}_{\mathbf{B}} / \mathbf{I}_{\mathbf{Q}}{ }^{c}$ & $\Delta v\left(\mathrm{~cm}^{-1}\right)^{d}$ \\
\hline 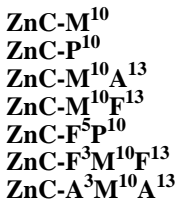 & $\begin{array}{l}405(13) \\
405(13) \\
418(18) \\
418(20) \\
425(29) \\
439(20) \\
436(21)\end{array}$ & $\begin{array}{l}606(12) \\
605(11) \\
632(14) \\
634(12) \\
650(36) \\
667(17) \\
662(18)\end{array}$ & $\begin{array}{l}4.3 \\
4.1 \\
2.1 \\
2.2 \\
6.2 \\
1.4 \\
1.5\end{array}$ & $\begin{array}{l}--- \\
--- \\
680 \\
730 \\
1100 \\
1500 \\
1400\end{array}$ \\
\hline $\begin{array}{l}\mathrm{ZnC}-T^{5} M^{10} \\
\mathrm{ZnC}-T^{5} M^{10} \mathrm{~F}^{15} \\
\mathrm{ZnC}-T^{5} M^{10} \mathrm{~F}^{13}\end{array}$ & $\begin{array}{l}412(13) \\
417(16) \\
424(15)\end{array}$ & $\begin{array}{l}608(11) \\
626(20) \\
637(13)\end{array}$ & $\begin{array}{l}5.0 \\
5.6 \\
2.6\end{array}$ & $\begin{array}{l}--- \\
470 \\
750\end{array}$ \\
\hline $\begin{array}{l}\text { FbC-M } M^{10} \\
\text { FbC-P } \\
\text { FbC-M } \\
\text { FbC-T }{ }^{5} \mathbf{F}^{10} \mathbf{M}^{10} \mathbf{F}^{13} \\
\text { FbC-F } \mathbf{F}^{50}\end{array}$ & $\begin{array}{l}400(34) \\
403(34) \\
414(35) \\
422(36) \\
416(41)\end{array}$ & $\begin{array}{l}637(9) \\
637(9) \\
659(11) \\
663(11) \\
672(27)\end{array}$ & $\begin{array}{l}2.7 \\
2.8 \\
1.9 \\
2.2 \\
5.0\end{array}$ & $\begin{array}{l}--- \\
--- \\
520 \\
620 \\
820\end{array}$ \\
\hline
\end{tabular}

$a_{\text {In toluene at room temperature. }}$

${ }^{b}$ All compounds that are not synthesized herein are described in ref. 19.

${ }^{c}$ Ratio of the intensities of the B and $\mathrm{Q} y$ bands.

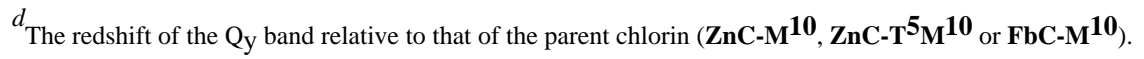

